\title{
Mapping of seagrass and seaweed beds using hydro-acoustic methods
}

\author{
TERUHISA KOMATSU ${ }^{1}$, CHIAKI IGARARASHI ${ }^{1}$, KEN-ICHI TATSUKAWA ${ }^{1}$, MASAHIRO NAKAOKA ${ }^{1}$, \\ TOMONORI HIRAISHI ${ }^{2}$ AND ASAHIKO TAIRA ${ }^{1}$
}

1 Ocean Research Institute, The University of Tokyo, 1-15-1, Minamidai, Nakanoku, Tokyo, 164-8639, Japan (komatsu@ori.u-tokyo.ac.jp) and 2 Graduate School of Fisheries Science, Hokkaido University, 3-1·1 Minatocho, Hakodate 041-8611, Japan

SUMMARY: Mapping of seagrass and seaweed beds is very important for management and conservation of sound littoral ecosystems and sustainable fisheries in the coastal waters. The methods to map spatial distribution of seagrass and seaweed beds are reviewed. They are classified into two categories. One is a direct method by visual observation and the other is an indirect method using a remote sensing apparatus. Indirect methods are divided into optical or hydro-acoustic methods. Indirect methods require sea truth by direct methods. Optical methods are image analysis of aerial photography or satellite imagery. They are effective for mapping broad areas but limited to shallow waters due to light attenuation in waters. Hydro-acoustic methods such as an echosounder and a side scan sonar have no limitation of turbidity. The echosounder is practical to map vertically density and height distributions of seagrass and seaweed beds. The side scan sonar is appropriate for mapping broad horizontal distributions. Coupling of several indirect mapping methods is more useful than using only one method.

KEY WORDS: seagrass, seaweed, mapping, remote sensing, hydro-acoustic

\section{INTRODUCTION}

Seagrass and seaweed beds play an important role for marine coastal ecosystems. They support flora and fauna including epiphytic organisms, and coastal fisheries productivity ${ }^{1,2}$. Seagrass beds contribute to marine environment, for example, stabilizing bottom sediments, and maintaining coastal water quality and clarity $3,4,5,6$, , . Seaweed forests also have similar influences on marine environment as seagrass beds. For example, buffering effect on water flow, 7,8 , $\mathrm{pH}$ distributions"), dissolved oxygen distributions $\mathrm{s}^{11,11)}$ ' etc. Many important species spawn in the beds, for example, abalones, sea urchins, turban shells, balaos, cuttlefish etc. Their larvae and juveniles use the beds as a nursery ground ${ }^{12}$. In this way, the seagrass and seaweed beds serve as an important habitat for marine animals and support biodiversity.

An increase in seafloor reclamation and sewage from industries and agricultures has decreased large areas of seagrass and seaweed beds in the coastal zone during economic development in $\operatorname{Japan}^{13)}$ and U.S.A. ${ }^{14)}$. Since the seagrass and seaweed beds are sensitive to pollutions and water quality deterioration, they serve as a "bio-indicator". Change of seagrass depth distribution in Chesapeake
Bay ${ }^{15)}$ was the "bio-indicator" when runoff-impacts on water quality caused changes in light penetration and consequently affected seagrass abundance and distribution patterns. Using the lower bottom depth limit of Posidonia oceanica (L.) Delile as the "bio-indicator", a monitoring program has also been carried out at 24-33 survey sites along the Provence and French Riviera coasts since $1984^{16}$. Mapping of seagrass or seaweed beds is a practical method to know a condition of coastal environment.

Preservation, restoration and creation of seagrass and seaweed beds are, thus, necessary to recover coastal environment, biodiversity and bio-resources for sustainable development of fisheries. For this purpose, it is urgently required to establish precise and reliable techniques to map and monitor seagrass and seaweed beds in quantitative and efficient ways ${ }^{\prime n}$.

\section{CLASSIFICATION OF MAPPING METHODS}

Mapping methods of seagrass and seaweed beds are classified into two categories. One is a direct observation or measurement by researchers. The other is an indirect method using a remote sensing apparatus. Direct methods 
are ground surveys (walking, diving or grabs). In France, observation from a submarine was used to map lower bottom depth limit of $P$. oceanica beds along the French Riviera Coast ${ }^{18)}$. Direct methods are not efficient because they need time and persons to perform field surveys.

Indirect methods are classified into two groups by apparatuses for remote sensing: an optical remote sensing and acoustic remote sensing. In applying these two methods for mapping seagrass and seaweed beds, indirect methods essentially need ground truth ${ }^{17}$.

\section{OPTICAL REMOTE SENSING METHODS}

To map spatial distributions of seagrass beds, aerial photography and satellite imagery are generally used. Satellite images are of value for large-scale localization investigations ${ }^{19,21)}$. Aerial photographs can provide more detailed data for studying the horizontal distribution, monitoring the long-term change or estimating the biomass of seagrass beds ${ }^{21,22)}$. The aerial photographs and satellite imagery are efficient for mapping where dense seagrasses can be identified on very large scales ${ }^{19,23,24,25}$, but cannot always be used successfully to map seagrass or seaweed biomass or find those of low density or small patches, or in water too turbid or too deep for remote sensing ${ }^{26}$. Recently, towing video camera system ${ }^{27}$ has been developed. The camera is mounted in a 'down-looking' orientation on a towfish, which was deployed directly off the stern of the vessel using the cargo boom. However, it is also sensitive to turbidity.

\section{ACOUSTIC REMOTE SENSING METHODS}

One acoustic method to map seagrass beds using a side scan sonar, which is more efficient than that of the ground surveys, has been developed since 1970s in the Mediterranean Sea. It scanned sea bottom at a width ranging $50-500 \mathrm{~m}$, and could distinguish seagrass bed distributions and the others successfully ${ }^{28,29,30,31,32,33)}$. However, it is difficult for this method to measure densities and heights of plants along a transect. Great disadvantages are (1) expensiveness of the system, (2) difficult treatment of the system on the small boat in shallow waters and (3) difficult processing of horizontal distribution data to mapping data through position data of the ship.

Echosounders have been developed to detect distributions of fish schools and to measure underwater bottom topographies. They send out ultrasonic waves of a certain frequency in the water and measure their reflection by bottoms and objects in the sea. Because the reflection coefficient of ultrasonic depends on materials of objects, especially air content such as gas-filled vesicles of Sargassum species, we can identify the objects in clear cases. The echosounders have advantages not only to continuously measure biomass distributions and bottom topographies, but also to be used at a low cost and easy treatment. This method has been applied to several studies in phanerogam beds in lakes ${ }^{34)}$, seaweed beds ${ }^{35,36,37,38)}$, Zostera manina L. beds ${ }^{39)}$ and $P$. oceanica meadows ${ }^{4(1,41)}$.

Colantoni et al. ${ }^{40)}$ tried to use a low frequency echosounder $(3.5 \mathrm{kHz})$; it proved to be rather ineffective to discriminate the acoustic character between $P$. oceanica bed and the bottom. Although the high-resolution continuous seismic reflection ${ }^{4)}(3.5 \mathrm{kHz})$ could distinguish the $P$. oceanica and others, long wavelength of ultrasonic brings worse vertical precision of echosounder. Echosounders with an ultrasonic wave of $200 \mathrm{kHz}$ is more appropriate for detecting seagrass beds ${ }^{39,43)}$.

The echosounder can scan seagrass and seaweed beds when traveling at about $1.0-1.5 \mathrm{~m} / \mathrm{s}(2-3 \mathrm{knots})$. It is possible to investigate $37 \mathrm{~km}$ per day when a ship with an echosounder travels at $1 \mathrm{~m} / \mathrm{s}$ ( 2 knots) for ten hours. In this way, the echosounder is a very useful apparatus to map seagrass and seaweed beds.

\section{LOCALIZATION USING GPS SYSTEM}

Most of the studies mentioned in the previous section did not refer to a density distribution of plants along a transect by the echosounder in the sea, and have not been used for mapping so often. It is estimated that one of the reasons is that localization of vessels equipped with an echosounder was not easy with good precision. Two transit theodlites ${ }^{29,39)}$, $\mathrm{DECCA}^{29)}$, or a radio positioning system $^{41,42)}$ have been used as a localization system. The Global Positioning System (GPS) became available in 1980 s. It permits us to localize instantaneously the place scanned by the echosounder. The accuracy of GPS has been ameliorated from $\pm 36 \mathrm{~m}(95 \%)$ to $\pm 6 \mathrm{~m}(95 \%)$ since 2000 because of the removal of Selective Availability (SA) from GPS (stopping the intentional degradation of the GPS signals) on 2 May 2000. In the world, 34 countries have already installed Differential GPS radio beacon networks in territory of each country, and more are considering the adoption of this navigation standard. The improvement of the basic GPS signal through elimination of SA may allow the DGPS radio beacons to transmit fewer error corrections and more accurate localization. Accuracy of DGPS is about several decadal centimeters. The GPS is inexpensive system and more convenient and more available at any place for localization. The GPS or DGPS contribute in situ remote sensing and direct observation for mapping of seagrass and seaweed beds.

\section{QUANTIFICATION USING AN ECHOSOUNDER}

Hatakeyama and Maniwa ${ }^{39)}$ used the echosounder for 
mapping a Zostera bed, but they calculated only an index of biomass: sum of canopy heights by unit sector along transects scanned by the echosounder. Since it is necessary to estimate seagrass or seaweed biomass for a quantitative comprehension of the their ecosystems, Komatsu and Tatsukawa ${ }^{43)}$ propose a simple converting method from the shading grades of seagrass on echograms to above-ground biomass based on quadrat samplings. Tanaka and Tanaka ${ }^{38)}$ classified Sargassum beds along transects into four groups based on the canopy height on echograms because the canopy heights were related to biomass on a quadrat sampled along the transects. They estimated total biomass from surface area of each group. Using a scientific echosounder, Kitoh ${ }^{37}$ estimated biomass of seaweed beds.

\section{DETECTION OF VERTICAL DISTRIBUTION}

The position of the lower bottom depth limit of seagrass beds is related to the light extinction coefficient influencing the minimum degree of light required for growth of seagrass ${ }^{44)}$. Thus, it can be used for an indicator of water quality. In France, the lower bottom depth limit of $P$. oceanica was monitored by placing concrete markers ${ }^{45}$. In this case, obtained results are very precise, but the observed area is limited. The echosounder can be used to define the vertical distribution of seagrass bed and the lower bottom depth limit of seagrass beds by correcting depths measured by the echosounder to the mean sea level. Therefore, monitoring of the lower bottom depth by the echosounder is useful for detecting the lower bottom depth limit of seagrass beds not precisely but roughly in a wide area. When these two types of monitoring are coupled, they complement each other to obtain lower bottom depth limits.

Komatsu and Tatsukwa ${ }^{43}$ clarified that the canopy height was nearly proportional to the maximum blade length. By cropping blades of seagrass, the height of seagrass canopies on the echo-traces can be used as an indicator of the maximum blade length of seagrass when the current speeds were not greatly different over the beds. Tanaka and Tanaka ${ }^{38)}$ also reported a similar proportional relation between the canopy height and maximum frond lengths of Sargassum species. Komatsu et al. ${ }^{46}$ developed mapping methods using a multi-beam sonar that can send several decadal beams from the transducer and measure the bottom depths. They can measure height distribution of seagrass beds.

\section{CONCLUSION}

Seagrass and seaweed distributions are linked to physical, chemical and social environments or human impacts. Geographical Information Systems (GIS), the computer systems capable of assembling, storing, manipulating, and displaying geographically referenced information are practical tools for analyzing spatial and temporal change of seagrass and seaweed bed distributions.

A mapping method using an echosounder is a simple, laborsaving and efficient one to detect their canopy height and above-ground biomass and their upper and lower depth limits. Since a newly developed GPS system makes positioning of a boat more accurate, scanning of the beds becomes highly precise. Incorporating the cropping of plants in situ, we can estimate vertical and horizontal distributions of the beds, plant density, and a biomass distribution of the beds. On the other hand, a side scan sonar is very effective to horizontal mapping of seagrass and seaweed beds while it is complicated and expensive. It is expected that the acoustic mapping methods will become more effective by combining of not only those acoustic methods but also other direct and other optical remote sensing methods.

We thank to Dr. T. Nishida of National Institute for Far Seas Fisheries for his critical reading of our manuscript.

\section{REFERENCE}

1. Orth, R.J., Heck, K.LJ. and Van Monfrans, J. Faunal communities in seagrass beds. A review of the influence of plant structure and prey characteristics on predatory-prey relationships. Estuaries 1984; 7: 339-350.

2. Coles, R.G., Lee Long, WJ., Watson, R.A. and Derbyshire, KJ. Distribution of seagrasses, and their fish and penaeid prawn communities, in Cairns Harbour, a tropical estuary, northem Queensland, Australia. Aust. J. Mar. Freshwater. Res. 1993; 44: 193-210.

3. Ward, L.G., Kemp, W.M. and Boyton, W.R. The influence of waves and seagrass communities on suspended particulates in an estuarine embayment. Mar. Geo. 1984; 59: 85-103.

4. Jeudy de Grissac, A. and Boudoureque, C-F. Rôle des herbiers de Phanérogames marines dans les mouvements des sédiments côtiers : les herbiers à Posidonia oceanica. In Ceccaldi $\mathrm{HJ}$, Champalbert G. (eds) Acte du colloque pluridisciplinaire franco-japonais d'Océanographie Fiscicule 1, Société Franco-japonaise d'Océanographie, Marseille, 1985, pp.143-151.

5. Komatsu, T. and Nakaoka, M. Water flow and sedimentation rate in seagrass beds off Khao Bae $\mathrm{Na}$ in Trang Province, Thailand. Biologia Marina Mediterranea 2000; 7: 240-242.

6. Komatsu, T. and Yamano, $H$. Influence of seagrass vegetation on bottom topography and sediment distribution on a small spatial scale in the Dravuni Island Lagoon, Fiji. Biologia Marina Mediterranea 2000; 7: 243-246.

7. Komatsu, T. and Murakami, S. Influence of a Sargassum forest on the spatial distribution of water flow, Fish. Oceanogr. 1994; 3 : 256-266.

8. Mork, M. The effect of kelp in wave damping. SARSLA 1996; 80: 323-327.

9. Komatsu, T. and Kawai, H. Diumal changes of $\mathrm{pH}$ distributions and the cascading of shore water in a Sargassum forest, J. Oceanogr. Soc. Japan, 1986; 42: 447-458.

10. Komatsu, T. Day-night reversion in the horizontal distributions of dissolved oxygen content and $\mathrm{pH}$ in a Sargassum forest. $J$. 
Oceanogr. Soc. Japan 1989; 45: 106-115.

11. Komatsu, $T$., Kawai, $H$. and Sakamoto, W. Influences of Sargassum forest on marine environments. Bull. Costal Oceanogr. 1990; 27: 115-126. In Japanese with English abstract.

12. Arasaki, M. and Arasaki, T. Compilation of stories on algae. Tokai University Press, Tokyo, 1978, pp.1-228.

13. Hoshino, Y. Pollution in the Seto Inland Sea. Iwanami, Tokyo, 1972, pp.1-202. In Japanese.

14. Shor, F. and Willie-Echeverria, S. Natural and human-induced disturbance of seagrasses. Environmental Conservation 1996; 23: 17-27.

15. Dennison, W.C., Orth, R.J., Moore, K.A., Stevenson, J.C., Carter, V., Kollar, S, Bergstrom, P.W. and Batiuk, R.A. Assessing water quality with submerged aquatic vegetation: Habitat requirements as barometers of Chesapeak Bay health. BioScience 1993; 43: 86-94.

16. Boudouresque, C-F., Charbonel, E., Meinesz, A., Pergent, G., Pergent-Martini, C., Cadiou, G., Bertrandy, M.C., Foret, P., Ragazzi, M. and Rico-Raimondino, V. A monitoring network based on the seagrass Posidonia oceanica in the northwestern Mediterranean Sea. Biologia Marina Mediterranea 2000; 7: 328-331.

17. Lee Long, WJ., Mckenzie, LJ., Rasheed, M.A. and Coles, R.G. Monitoring seagrasses in tropical ports and harbours. In Kuo J, Phillips RC, Walker DI, Kirkman H (eds) Seagrass biology: Proceedings of an intemational workshop Rottnest Island, Westem Australia, 25-29 January 1996. Fac. Sci. Univ. West., Australia, Westem Australia, Nedlands, 1996, 345-350.

18. Meinesz, A., and Laurent, R. Cartographie et état de la limite inférieure de l'herbier de Posidonia oceanica dans les Alpes-maritimes (France) -Campagne Poseidon 1976-. Botanica Marina 1978; 21: 513-526.

19. Belsher, T. Apports du satellite SPOT à la cartographie des végétaux marins. La Mer 1989; 27: 144-145.

20. Fredj, G., Meinardi, M., Pierrot, S. and Roy, P. Cartographie par le satellite SPOT 1 de communautés benthiques littorales en Méditerranée occidentale. Bull. Inst. Oceanogr. 1990; 6: 71-85.

21. Meulstee, C., Nienhuis, P.H. and Van Stokkom, T.C. Biomass assessment of estuarine macrophytobenthos using aerial photography. Mar. Biol 1986; 91: 331-335.

22. Meinesz, A., Boudouresque, C-F. and Lefevre, J.R. A map of the Posidonia oceanica beds of Marina d'Elbu (Corsica, Mediterranean). Marine Ecology P.S.Z.N. 1988; 9: 243-252.

23. Belsher, T., Meinesz, A., Lefêvre, J.R., and Boudoureque, C-F. Simulation of SPOT satellite for charting shallow-water benthic communities in the Mediterranean. Marine Ecology P.S.Z.N. 1988; 9: 157-165.

24. Kirkman, H. Seagrass distribution and mapping. In Phillips RC, McRoy CP (eds) Seagrass research methods. Monographs on oceanographic methodology, UNESCO, Paris, 1990, pp.19-25

25. Long, B.G., Skews, I.D. and Pointer, I.R. An efficient method for estimating seagrass biomass. Aquat. Bot. 1994; 47: 277-292.

26. Pasqualini, V. and Pergent-Martini, C. Monitoring of Posidonia oceanica meadows using image processing. In Kuo J, Phillips RC, Walker DI, Kirkman H (eds) Seagrass biology: Proceedings of an international workshop Rottnest Island, Westem Australia, 25-29 January 1996. Fac. Sci. Univ. West., Australia, Westem Australia, Nedlands, 1996, 351-358.

27. Norris, J.G., Wyllie-Echeverria, S., Mumford, T., Bauley, A. and Tumer, $T$. Estimating basal area coverage of subtidal seagrass beds using underwater videography. Aquat. Bot. 1997; 58: 269-287.

28. Newton, R.S. and Stefanon, A. Application of side scan sonar in marine biology. Mar. Biol. 1975; 31: 287-291.

29. Meinesz, A. Cuvelier, M. and Laurent, R. Méthode récentes de cartographie et de surveillance des herviers de Phanérogames marines. Vie et Milieu 1981; 31: 27-34.

30. Lefevre, J.R., Meinesz, A. and Gloux, B. Premières données sur la comparaison de trois méthôdes de cartographie des biocénoses marines. Rapport PV Reun. Comm. Internation. Explor. Sci. Medit. 1984; 29: 209-211.

31. Gloux, B. Méthode acoustiques et informatiques appliquées à la cartographie rapide et détaillée des herbiers. In Boudouresques C.-F., Jeudy de Grissac A, Olivier J. (eds) International Workshop on Posidonia oceanica Beds. GIS Posidonie Press, Marseille, 1984, pp. 45-48.

32. Ramos, M.A. and Ramos-Espla, A. Utilization of acoustic methods in the cartography of the Posidonia oceanica bed in the bay of Alicante (SE, Spain). Posidonia Newsletter 1989; 2: 17-19.

33. Pasqualini, V., Pergent-Martini, C., Clabaut, P. and Pergent, G. Mapping of Posidonia oceanica using aerial photographs and side scan sonar: Application off Island of Corsica (France). Estuarine Coast. Shelf Sci. 1998; 47: 359-367.

34. Duarte, C. M. Use of echosounder tracings to estimate the above ground biomass of submerged plant in lakes. Can. J. Fish. Aquat. Sci. 1987; 44: 732-735.

35. Hashimoto, T. and Nishimura, M. Sounding of artificial schools, rocksand, sea plants fields by fish finder. Tech Rep. Fishing Boat 1953; 4: 138-142. In Japanese.

36. Hashimoto, T. and Nishimura, M. Study on detection of Japanese tang field by the ultrasonic fish-finder. Tech. Rep. Fishing Boat 1953; 5: 187-194 . In Japanese.

37. Kitoh, H. Seaweed beds research by a scientific echosounder. Seikai Reg. Fish. Res. Inst. News 1983; 43: 2-4 . In Japanese

38. Tanaka, $M$. and Tanaka, $K$. On the estimation of the abundance of seaweed in coastal area I, estimation by echosounder. Fisheries Civil Engineering 1985; 21: 17-23. In Japanese.

39. Hatakeyama, Y. and Maniwa, Y. On the investigation of seaweed distribution by utilizing the fish finder. Tech. Rep. Fishing Boat 1978; 73: 155-168. In Japanese.

40. Colantoni, P., Gallignani, P., Fresi, E. and Cinelli, F. Patterns of Posidonia oceanica (L.) Delile beds around the Island of Ischia (Gulf of Naples) and in adjacent waters. Marine Ecology P.S.Z.N., 1982; 3: 53-74.

41. Rey, J. and Diaz del Rio, V. 1989. Cartographia de los fondos marinos de la Bachia de Palma (Baleares, Espana): Distribution de las praderas vegetales $\mathrm{y}$ sedimentos superficiales. In Boudouresques C-F, Meinesz A, Fresi E, Gravez V (eds), International Workshop on Posidonia beds 2 GIS. Posidonie Press, Marseille, 1989, pp. 29-41.

42. Calvo, S., Frada Osterano, C. and Abbadessa, P. The suitability of a topographical instrument for an integrated approach to the cartography of Posidonia oceanica meadows. Oceanologica Acta 1993; 16: 273-278.

43. Komatsu, T. and Tatsukawa, K. Mapping of Zostera marina L. beds in Ajino Bay, Seto Inland Sea, Japan, by using echosounder and global positioning systems. J. Recherche Océanogr. 1998; 23: 39-46.

44. Duarte, C.M. Seagrass depth limits. Aquat. Bot. 1991; 40: 363-377.

45. Meinesz, A. Balisage de la limite inférieure de l'herbier de Posidonia oceanica en rade de Villefranche-sur-Mer (Alpes-Maritimes, France) Rapport P. V. Réunion Comm. Int. Explor. Sci. Medit. 1977; 24: 143-144.

46. Komatsu, T., Igarashi, C., Tatsukawa, K and Matuoka, Y. Mapping seagrass meadows using a multi-beam sonar. (submitled) 